\title{
Calcium and sodium as regulators of the recovery of four Daphnia species along a gradient of metals and base cations in metal contaminated lakes in Sudbury, Ontario, Canada
}

\author{
Martha Patricia CELIS-SALGADO,,$^{*}$ Wendel (Bill) KELLER, ${ }^{2}$ Norman D. YAN ${ }^{1,3}$ \\ ${ }^{1}$ Biology Department, York University, Field Laboratory for the Assessment of Multiple Environmental Stressors, Dorset, Ontario, \\ Canada. P.O. Box 39, Dorset, ON., Canada P0A 1E0; ${ }^{2}$ Cooperative Freshwater Ecology Unit, Vale Living with Lakes Centre, Laurentian \\ University, 935 Ramsey Lake Road, Sudbury, ON., Canada P3E 2C6; ${ }^{3}$ Dorset Environmental Science Centre P.O. Box 39, Dorset, ON., \\ Canada P0A 1E0 \\ *Corresponding author: mpcs@queensu.ca
}

\begin{abstract}
Smelting of sulphur-rich metallic ores in Sudbury, Ontario, Canada, has caused acidification and metal contamination of thousands of lakes in the region. Recent reductions in smelter emissions have resulted in much ecological recovery, but the recovery of Daphnia species has been poor. To determine if $\mathrm{Cu}$ and Ni toxicity could explain differences in daphniid recovery among lakes, we compared results of 14 d static with renewal bioassays in waters from Blue Chalk Lake, an uncontaminated reference lake $200 \mathrm{~km}$ from Sudbury, and from five Sudbury lakes ranging in distance from the smelters and varying in metal and cation concentrations. We spiked Blue Chalk Lake water with $\mathrm{Cu}$ and Ni to levels resembling those of the Sudbury lakes and also tested the lake waters for toxicity. Survival of Daphnia pulex, D. pulicaria and D. mendotae decreased monotonically with increasing metal concentrations in the spiked Blue Chalk Lake treatments, falling from $90 \%$ in the controls to $0 \%$ at the two highest $\mathrm{Cu}$ and Ni levels, reflecting levels of Middle and Hannah lakes. In contrast, survival in waters collected from the actual Sudbury lakes did not monotonically track their total metal concentrations. Rather, survival fell to $0 \%$ in Clearwater Lake water, a lake with intermediate metal contamination $\left(8.9\right.$ and $79.9 \mu \mathrm{g} \mathrm{L}^{-1}$ of Cu and Ni, respectively) vs 70-100\% in the other lakes. We performed an additional assay with Clearwater Lake waters increasing its Ca and Na concentrations, singly and in combination to levels that reflected the levels in Middle Lake. The survival of the four daphniid species increased from $0 \%$ up to $80-100 \%$ with added Ca and from $0 \%$ to 60-90\% with added Na. Lipid-ovarian indices had a similar trend to survival for D. mendotae and D. pulicaria in Bioassay 1, varying with the cation concentrations in the lakes for the daphniids in Bioassay 2. The bioassays results imply that regional recovery patterns of daphniids in Sudbury lakes cannot be understood without as a minimum considering both metal and base cation concentration differences among lakes, and give an indication of differences among Daphnia species to cope with metal stress.
\end{abstract}

Key words: Daphnia; Sudbury lakes; copper; nickel; calcium; sodium.

Received: May 2015. Accepted: August 2015.

\section{INTRODUCTION}

A meteorite impacted the earth 1.85 billion years ago, in what today is the region of Sudbury, Ontario, Canada, leaving a metal-rich ore body currently known as The Sudbury Structure (Boerner et al., 2000; Roussell et al., 2003). The dominant metal-bearing ore in the Sudbury Structure is a pentlandite (an iron-nickel sulphide) with chalcopyrite (an iron-copper sulphide) as an accessory mineral; it also contains aluminum, manganese, zinc, lead, platinum and gold (Mason, 1966; Roussell et al., 2003). This ore body has been mined and locally smelted in Sudbury for over 100 years; as there are thousands of softwater, Canadian Shield lakes in this region, a great number of lakes have been contaminated.

The local, ground-level roasting of this ore, replaced after 1930 by local smelting, released enormous quantities of metals and sulphur dioxide into the atmosphere (Lesher and Thurston, 2002) which then impacted the local watersheds as metal-laden acid rain and snow, dry deposition of metal particulates and/or direct $\mathrm{SO}_{2}$ adsorption on surfaces. The acid and metal inputs, coupled with the massive deforestation to fuel the original roast beds, impacted an area of $\sim 17,000 \mathrm{~km}^{2}$, which included 7000 lakes (Keller and Pitblado, 1984; Keller et al., 1990, 1999). Metal levels were highest in lakes with direct tailings drainage, but lakes receiving only atmospheric inputs and watershed runoff were not spared.

Significant efforts to reduce the acid and metal damage in Sudbury lakes began in the 1970s. In response to regulations, plus changing corporate and societal attitudes to the environment, Sudbury's metal industries dramatically reduced $\mathrm{SO}_{2}$ and metal emissions. The reduction of the atmospheric emissions diminished the deposition of acid and metals to local watersheds and lakes, and the water quality 
of many previously impacted lakes improved with time (Keller and Pitblado, 1984; Keller et al., 1999; Jeffries et al., 2003; Keller, 2009; Valois et al., 2011; Webster et al., 2013). Recovery of some lakes was also accelerated by addition of calcareous materials (i.e., liming) to these lakes and their watersheds, including Middle and Hannah (Yan et al., 1996b). For example, in 1973, Hannah Lake, which is located only $4.3 \mathrm{~km}$ from the main smelter complex, had among the highest metal levels of local urban lakes, averaging $1108 \mu \mathrm{g} \mathrm{L}-1$ of $\mathrm{Cu}$ and $1865 \mu \mathrm{g} \mathrm{L}^{-1}$ of $\mathrm{Ni}$ at a $\mathrm{pH}$ of 4.29 (Yan et al., 1996a). By 2006, reflecting diverse restoration efforts and reduced emissions, the concentrations of those metals had plummeted to $20.8 \mu \mathrm{g} \mathrm{L}^{-1}$ of $\mathrm{Cu}$ and $133.0 \mu \mathrm{g} \mathrm{L} \mathrm{L}^{-1}$ of $\mathrm{Ni}$ (Tab. 1).

Ecological recovery is a complex process requiring the rebuilding of both functional and structural components of ecosystems. Some would consider a system recovered once all of its dynamic characteristics are restored (for example the return of previous levels of primary production, herbivory, predation, etc.). Others would argue that recovery also requires the restoration of all species with relative abundances resembling those observed either prior to the disturbance or typical of undamaged reference lakes (Yan et al., 1996a). The severity and duration of the historical contamination in Sudbury has complicated ecological recovery, given that so many species disappeared, and potential colonist pools have also been damaged by metal contamination, and possibly by other stressors such as climate change (Keller et al., 2007). Still, in response to the local water quality improvements (Keller et al., 2003), some zooplankton and fish have recovered in Sudbury lakes (Gunn and Keller, 1990; Yan et al., 2004; Keller et al., 2007).

Gunn and Sandoy (2003) argued that biological recovery requires that a number of healthy key organisms and sensitive species, including fish, phytoplankton, zooplankton and benthic invertebrates re-establish viable populations and resume their role in the system, such that the restored community resembles one in similar ecosystems with minimal anthropogenic impact. However, a lost species can only recover if there is habitat of sufficient quality for founding populations to persist (Griffith et al., 1989; Keller et al., 1999). Such biological recovery has been both slow and incomplete in Sudbury's urban lakes (Yan et al., 2004, Keller et al., 2007). Water quality has improved significantly (Keller et al., 1999; Keller, 2009; Khan et al., 2012) and daphniid colonists have arrived, but most have failed to re-establish populations (Yan et al., 2004; Schartau et al., 2007). Acidity is no longer the problem since the majority of Sudbury lakes now have $\mathrm{pH}>6.0$, a safe $\mathrm{pH}$ for Cladocera (Havens et al., 1993; Holt andYan, 2003); hence, attention has turned to lingering metal problems.

Daphniids are common in Canadian Shield lakes (Keller and Pitblado, 1989). There are about 7 species native to the Shield (Hebert, 1995), and, as a group, they are considered to be among the most important pelagic herbivores, maintaining water clarity and providing food for fish. They are also among the most sensitive freshwater invertebrates to adverse water quality conditions (Koivisto and Ketola, 1995; Hairston et al., 2005), therefore, their failure to re-establish populations in many Sudbury lakes is a concern (Yan et al., 2004). Above their required concentrations, essential metals such as $\mathrm{Cu}$ become toxic (Mertz, 1981), reducing the survival (Bielmeyer et al., 2005) and reproduction of daphniids (Koivisto and Ketola, 1995), also altering their energy budgets and reducing the accumulation of lipids (Canli, 2006).

Competing explanations for the lack of recovery of daphniid species in Sudbury lakes have not as yet been experimentally evaluated. Yan et al. (2004) hypothesized that the delayed recovery of common daphniids in circumneutral but historically acidified and metal contaminated Sudbury lakes was attributable either to ongoing $\mathrm{Cu}$ and $\mathrm{Ni}$ toxicity, and/or to heavy predation on large Cladocera from planktivorous yellow perch (Perca flavescens) pres-

Tab. 1. Selected morphometric, geographic and chemical data for the six study lakes.*

\begin{tabular}{|c|c|c|c|c|c|c|c|c|c|c|}
\hline Lake & $\begin{array}{l}\text { Lake } \\
\text { area } \\
\text { (ha) }\end{array}$ & $\begin{array}{l}\text { Lake } \\
\text { volume } \\
\left(\mathrm{m}^{3} 10^{5}\right)\end{array}$ & $\begin{array}{l}\text { Mean } \\
\text { depth } \\
\text { (m) }\end{array}$ & $\begin{array}{l}\text { Maximum } \\
\text { depth } \\
\text { (m) }\end{array}$ & $\begin{array}{l}\text { Distance } \\
\text { from } \\
\text { the nearest } \\
\text { idbury smelter } \\
\text { (km) }\end{array}$ & $\mathrm{pH}$ & $\begin{array}{c}\mathrm{Cu} \\
\left(\mu \mathrm{g} \mathrm{L}^{-1}\right)\end{array}$ & $\begin{array}{c}\mathrm{Ni} \\
\left(\mu g \mathrm{~L}^{-1}\right)\end{array}$ & $\begin{array}{c}\mathrm{Ca} \\
\left(\mathrm{mg} \mathrm{L}^{-1}\right)\end{array}$ & $\begin{array}{c}\mathrm{Na} \\
\left(\mathrm{mg} \mathrm{L}^{-1}\right)\end{array}$ \\
\hline Blue Chalk & 49.0 & 42.1 & 8.5 & 23.0 & 200.0 & 7.1 & 0.29 & 0.19 & 2.54 & 0.77 \\
\hline Joe & 180.0 & 201.0 & 11.2 & 34.0 & 29.0 & 6.8 & 2.0 & 7.0 & 2.55 & 0.97 \\
\hline Lohi & 40.5 & 25.0 & 6.2 & 19.5 & 11.0 & 6.7 & 9.8 & 64.1 & 4.29 & 5.6 \\
\hline Clearwater & 76.5 & 64.2 & 8.3 & 21.5 & 13.0 & 6.3 & 8.9 & 79.9 & 4.06 & 4.53 \\
\hline Middle & 28.2 & 17.5 & 6.2 & 15.0 & 5.0 & 7.1 & 19.4 & 105.8 & 9.58 & 34.08 \\
\hline Hannah & 27.3 & 10.8 & 4.0 & 8.5 & 4.3 & 7.8 & 20.8 & 133.0 & 10.37 & 57.26 \\
\hline
\end{tabular}

*Data courtesy of the Ontario Ministry of the Environment and Climate Change 2006; Keller W, unpublished data. 
ent in the lakes (Luek et al., 2010). The latter, given the delayed re-colonization by piscivorous fish (Lippert et al., 2007; Luek et al., 2010). A third possibility is that there is, as yet, insufficient food for the daphniids, either in type, quantity or in quality (Nicholls et al., 1992; Graham et al., 2007).

Our objectives were: i) to determine if the $\mathrm{Cu}$ and $\mathrm{Ni}$ levels in Sudbury lakes were still toxic to daphniids, ii) to determine if $\mathrm{Ca}$ and $\mathrm{Na}$ concentrations of these lakes differed enough to affect the toxicity of those metals in the lakes; and iii) to determine if additions of $\mathrm{Ca}$ and $\mathrm{Na}$ to Clearwater Lake would increase the survival of the daphniids. We hypothesized: (1) that daphniid survival would be negatively correlated with $\mathrm{Cu}$ and $\mathrm{Ni}$ levels in a single, natural, soft-water source supplemented with metals to reflect the concentrations of a selected suite of lakes in Sudbury, where daphniid colonists have appeared but failed to persist, (2) that daphniid survival in the actual waters of Sudbury lakes would be influenced by the varying concentrations of cations in the lakes; and (3) that by increasing the $\mathrm{Ca}$ and $\mathrm{Na}$ concentrations in Clearwater Lake we could find a modified survival response in the test daphniids.

\section{METHODS}

\section{Lake selection}

Six Canadian Shield lakes were selected for this study: one reference soft water lake in the District of Muskoka (Blue Chalk Lake), and five metal-contaminated lakes in and near Sudbury (Joe, Lohi, Clearwater, Middle and Hannah lakes) (Fig. 1). The Sudbury lakes had different $\mathrm{Cu}$ and $\mathrm{Ni}$ concentrations constituting a metal gradient that is typical of urban, suburban and more remote lakes that differ in their distance from current and historical metal smelter complexes. Among them, Middle and Hannah lakes were experimentally limed in the early 1970s and their catchment areas limed in the early 1980s, additions considered to have had long-term effects on the lakes (Yan et al., 1996a; Keller et al., 1999; Keller et al., 2007).

The study lakes range not only in $\mathrm{Cu}$ and $\mathrm{Ni}$ levels but also in $\mathrm{Ca}$ and $\mathrm{Na}$ (Ontario Ministry of the Environment and Climate Change, monitoring data 1970-2014). The gradient of $\mathrm{Cu}$ and $\mathrm{Ni}$ increases in the following order: Joe Lake $<$ Lohi Lake $<$ Clearwater Lake $<$ Middle Lake $<$ Hannah Lake, due to their decreasing distance to the main smelter complex (Tab. 1). Morphometric, geographic and chemical background information on the lakes is provided by Keller and Yan (1991) and Faulkenham et al. (2003).

We selected these lakes because of their locations with respect to the smelters, the resultant gradient in metal concentrations in the water and the availability of almost 40 years of zooplankton monitoring data from the Ontario Ministry of the Environment and Climate Change, which provided evidence of failures in the re-establishment of the daphniid colonists (Yan et al., 2004; Webster et al., 2013).

\section{Bioassays}

We conducted bioassays using Daphnia pulex, D. pulicaria, D. mendotae and D. ambigua, all of which were collected from the Muskoka area of Ontario, Canada, a non-metal contaminated region of Canadian Shield lakes, roughly $200 \mathrm{~km}$ southeast of Sudbury. Three sets of bioassays were run. To test hypothesis 1 , we added $\mathrm{Cu}$ and $\mathrm{Ni}$ to waters collected from Blue Chalk Lake - a non-acidic, non-metal-contaminated reference lake in Muskoka, with a stable, multi-species assemblage of daphniid populations (Yan et al., 2008). Lake water was spiked with $\mathrm{Cu}$ and Ni solutions to reflect levels in the suite of Sudbury lakes (Bioassay 1). To address our second hypothesis, a bioassay with the four daphniid species was run in actual waters collected from Joe, Lohi, Clearwater, Middle and Hannah lakes, our suite of Sudbury lakes with respectively increasing metal levels and varying $\mathrm{Ca}$ and $\mathrm{Na}$ concentrations (Bioassay 2). Finally to test hypothesis 3 we ran another bioassay with Clearwater Lake water spiked with $\mathrm{Ca}$ and $\mathrm{Na}$ to the concentration of these cations present in Middle Lake (Bioassay 3).

Fourteen day static bioassays with $48 \mathrm{~h}$ media renewals, were run at $20^{\circ} \mathrm{C}$ with a $16: 8 \mathrm{~h}$ light:dark cycle in Conviron E7/2 light and temperature-controlled growth chambers in York University's FLAMES laboratory (Field Laboratory for the Assessment of Multiple Ecological

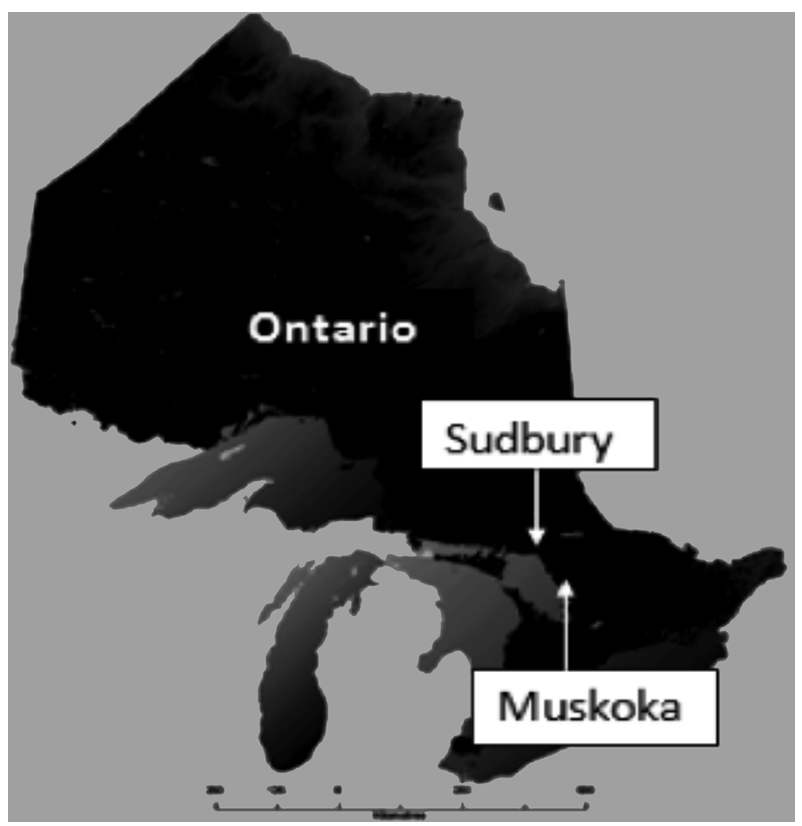

Fig. 1. Map of Ontario showing the study lakes area (Sudbury), and the reference lake and culture source location (Muskoka). 
Stressors) located at the Ontario Ministry of the Environment and Climate Change's Dorset Environmental Science Centre (DESC), in Dorset, Ontario, Canada. In the first 2 bioassays the controls were the FLAMES medium, a fully chemically defined, soft-water medium (Celis-Salgado et al., 2008), and Blue Chalk Lake water, the lake whose major element chemistry the FLAMES medium was designed to simulate. Double controls were employed in order to determine if there was any significant difference in survival that might be attributable to natural dissolved organic matter which the FLAMES medium does not include. The metal concentrations used in this bioassay were similar to those in the selected Sudbury lakes (Tabs. 1 and 2). In the Clearwater Lake experiment (Bioassay 3) the $\mathrm{Ca}$ and $\mathrm{Na}$ spikes were similar to those found in Middle Lake (Tabs. 1 and 3).

The metals and cations added to the Blue Chalk and Clearwater Lake waters were from stock solutions prepared with analytical grade reagents (Merck) as sulfate salts, except for $\mathrm{Na}$ which was added as $\mathrm{NaCl}$. All media were prepared $24 \mathrm{~h}$ prior to setting up the experiments or refreshing treatment media. The lake water was held at $4^{\circ} \mathrm{C}$ but was brought to $20^{\circ} \mathrm{C}$ in the culture chambers prior to adding food, setting or changing the daphniids to prevent temperature shock.

During rearing and in the experiments all animals were fed. To assure that the amount of food provided was not influencing animal survival, we followed Gliwicz (1990) rec- ommendations, and provided the daphniids with $1 \mathrm{mg}$ of particulate $\mathrm{C} \mathrm{L}^{-1} \mathrm{day}^{-1}$, as a mixture of the green algae Pseudokirchneriella subcapitata and Scenedesmus obliquus. The algae were separately cultured in Bold's Basal Medium, harvested in log phase, and settled for $24 \mathrm{~h}$ at $4^{\circ} \mathrm{C}$. The supernatant medium was discarded and the algae were re-suspended in appropriate treatment media before administering it as food in the experiments.

Bioassays were set up with one individual per $40 \mathrm{~mL}$ of treatment water. There were 10 replicates per treatment, which were checked daily for survival and neonate production. The metrics scored were: survival at day 14, and lipid ovary index (LOI) (Tessier and Goulden, 1982). These are factors related to physiological performance and therefore should be related to the potential for reestablishment of daphniids under metal stress. The LOI was recorded at the end of the experiment to aid in our understanding of the physiological responses to the metal stress; it was useful to determine the availability of energy in the form of lipids under the different treatments, as it is a factor that influences survival and reproduction.

We used distributional data analysis to test for normality (Kolmogorov-Smirnov), a 2 factor ANOVA with replication (treatment or lake water and daphniid species) for the absolute survival data; due to a non-normal LOI distribution, those data were transformed using the equation $\log 10(\mathrm{LOI}+1)$ prior to analyses. We used Tukey's post$h o c$ test when differences in the ANOVAS were found.

Tab. 2. $\mathrm{Cu}, \mathrm{Ni}, \mathrm{Ca}, \mathrm{Na}$ and $\mathrm{pH}$ in the Blue Chalk Lake water $(\mathrm{BC})$ treatments used in Bioassay 1: Blue Chalk lake water spiked with $\mathrm{Cu}$ and $\mathrm{Ni}$ to concentrations similar to those present in the studied Sudbury lakes (corresponding lakes indicated).

\begin{tabular}{|c|c|c|c|c|c|}
\hline Treatment (lake) & $\begin{array}{c}\mathrm{Cu} \\
\left(\mu \mathrm{g} \mathrm{L}^{-1}\right)\end{array}$ & $\begin{array}{c}\mathrm{Ni} \\
\left(\mu \mathrm{g} \mathrm{L}^{-1}\right)\end{array}$ & $\begin{array}{c}\mathrm{Ca} \\
\left(\mathrm{mg} \mathrm{L}^{-1}\right)\end{array}$ & $\begin{array}{c}\mathrm{Na} \\
\left(\mathrm{mg} \mathrm{L}^{-1}\right)\end{array}$ & $\begin{array}{c}\text { pH } \\
\text { (units) }\end{array}$ \\
\hline Flames medium & 0.29 & 0.19 & 2.54 & 0.77 & 6.65 \\
\hline Blue Chalk & 0.29 & 0.19 & 2.54 & 0.77 & 6.94 \\
\hline BC1 (Joe) & 2 & 7 & 2.54 & 0.77 & 6.94 \\
\hline BC2 (Lohi) & 10 & 60 & 2.54 & 0.77 & 6.95 \\
\hline BC3 (Clearwater) & 10 & 80 & 2.54 & 0.77 & 6.99 \\
\hline BC4 (Middle) & 20 & 100 & 2.54 & 0.77 & 6.97 \\
\hline BC5 (Hannah) & 20 & 140 & 2.54 & 0.77 & 6.91 \\
\hline
\end{tabular}

Tab. 3. $\mathrm{Cu}, \mathrm{Ni}, \mathrm{Ca}, \mathrm{Na}$ and $\mathrm{pH}$ in the treatments for Bioassay 3: Clearwater Lake water spiked with $\mathrm{Ca}$ and $\mathrm{Na}$ to the concentrations of those cations present in Middle Lake.

\begin{tabular}{|c|c|c|c|c|c|}
\hline Treatment & $\begin{array}{c}\mathrm{Cu} \\
\left(\mu \mathrm{g} \mathrm{L}^{-1}\right)\end{array}$ & $\begin{array}{c}\mathrm{Ni} \\
\left(\operatorname{\mu g} \mathrm{L}^{-1}\right)\end{array}$ & $\begin{array}{c}\mathrm{Ca} \\
\left(\mathrm{mg} \mathrm{L}^{-1}\right)\end{array}$ & $\begin{array}{c}\mathrm{Na} \\
\left(\mathrm{mg} \mathrm{L}^{-1}\right)\end{array}$ & $\mathrm{pH}$ \\
\hline Clearwater Lake water & 8.0 & 64.1 & 4.06 & 4.53 & 6.50 \\
\hline Clearwater Lake water $+\mathrm{Ca}$ & 8.0 & 64.1 & 9.60 & 4.53 & 6.51 \\
\hline Clearwater Lake water $+\mathrm{Na}$ & 8.0 & 64.1 & 4.06 & 35.6 & 6.52 \\
\hline Clearwater Lake water $+\mathrm{Ca}$ and $\mathrm{Na}$ & 8.0 & 64.1 & 9.60 & 35.6 & 6.48 \\
\hline
\end{tabular}




\section{Media}

The FLAMES medium (Celis-Salgado et al., 2008) was prepared with $>18.3$ megOhm water from Paint Lake (Dorset, ON.), the raw water source for the DESC. The site water was first de-chlorinated over activated charcoal and passed through 5 and $1 \mu \mathrm{m}$ particle filters. Then, it was run through two sequential cleaning and deionizing systems in the laboratory: a Zenon RO/DI system (Zenopure Laboratory Water System Ultra 70) followed by a Labconco Water Pro PS Station (Model 9000501).

All lake water used for the experiments was collected from each of the lakes in plasticware pre-cleaned with a sequence of basic, acid and distilled water rinses to remove both organic materials and metals. Lake water was collected from a deep, offshore, epilimnetic location, $2 \mathrm{~m}$ above the metalimnion in each lake. It was pumped at low speed $\left(0.33 \mathrm{~L} \mathrm{~s}^{-1}\right)$ and filtered to remove all coarse suspended matter through $80 \mu \mathrm{m}$ mesh, then through a set of portable $50 \mu \mathrm{m}$ and $25 \mu \mathrm{m}$ filters in the field and, subsequently through $5 \mu \mathrm{m}, 1 \mu \mathrm{m}$ and $0.35 \mu \mathrm{m}$ filters in the laboratory. The filtered lake water was then refrigerated at $4^{\circ} \mathrm{C}$ until use in the assays.

At the time of collection, the $\mathrm{Cu}$ concentrations ranged from 2 to $20.8 \mu \mathrm{g} \mathrm{L}^{-1}$ in the Sudbury lakes (Joe, Lohi, Clearwater, Middle and Hannah lakes) compared with $0.29 \mu \mathrm{g} \mathrm{L}^{-1}$ in the reference lake (Blue Chalk Lake). Nickel concentrations ranged from $7 \mu \mathrm{g} \mathrm{L}^{-1}$ to $133.0 \mu \mathrm{g} \mathrm{L}^{-1}$ compared with $0.19 \mu \mathrm{g} \mathrm{L}^{-1}$ in Blue Chalk Lake. The nominal $\mathrm{Cu}$ and $\mathrm{Ni}$ test concentrations applied in the Blue Chalk Lake water bioassays run to test our first hypothesis closely matched the gradient observed in Sudbury lakes for the two metals. The treatments are identified as $\mathrm{BC} 1$ similar to Joe Lake, BC2 similar to Lohi Lake, BC3 similar to Clearwater Lake, BC4 similar to Middle Lake and BC5 similar to Hannah Lake (Tab. 2).

\section{Chemical analyses}

Dissolved oxygen (Thermo Electron Corporation Orion $862 \mathrm{~A}$ ) and $\mathrm{pH}$ (Thermo Orion 520A plus) were measured in all experiments before adding the food to the media and before each renewal of the media. The $\mathrm{pH}$ electrode was calibrated before each set of readings with buffers at $\mathrm{pH} \mathrm{4,7}$ and 10 (Merck). Acidity was not altered appreciably from field levels in the treatments, and was never high enough to raise any concerns for the daphniids. The $\mathrm{pH}$ in the Blue Chalk Lake experiment ranged from 6.65 to 6.91 with an average of 6.90 (Tab. 2). In the bioassays using actual Sudbury lakes water, treatment $\mathrm{pH}$ remained similar to that of the corresponding lake (Tab. 1). In the Clearwater Lake water bioassay, the $\mathrm{pH}$ levels were between 6.48 and 6.52 with an average of
6.50 (Tab. 3). Oxygen levels did not affect survival, i.e. levels were $>8.0 \mathrm{mgL}^{-1}$ in all treatments at all times, considered as safe for the daphniids (FAO, 1996). Calcium and $\mathrm{Na}$ were determined for Bioassay 3 (hypothesis 3 ) in stock solutions before and twice during the test (Ontario Ministry of the Environment 2005, analytical method E3249 for cations). Metal levels in Blue Chalk Lake and in the suite of lakes in Sudbury were determined at the laboratory of the Ontario Ministry of the Environment and Climate Change in Rexdale, ON, Canada (Ministry of the Environment and Climate Change, Current/active LSB analytical method E3386 for metals).

\section{Daphnia species}

Daphnia pulicaria, D. mendotae and D. ambigua were collected from non-acidic, and non-metal contaminated lakes in the District of Muskoka, Ontario, Canada; specifically from Red Chalk Lake, Harp Lake and Rideout Lake, respectively. The source of $D$. pulex, the fourth species used, was a pond on the Sherbourne Lake Access Road, south of Dorset, Ontario, also in the District of Muskoka; Ashforth and Yan (2008) provide more details on this species' source. The daphniids were cultured in the FLAMES medium (Celis-Salgado et al., 2008) in Conviron E7/2 growth chambers at $20^{\circ} \mathrm{C}$ and under a $16: 8$ light:dark cycle. The clonal lines of each species have been maintained in healthy cultures in FLAMES medium in the FLAMES laboratory (York University, Dorset, Ontario, Canada) since 2006.

\section{RESULTS}

\section{Survival}

Daphniid survival decreased monotonically with increasing metal levels added to Blue Chalk Lake water, but the pattern of survival was very different in the actual water collected from Sudbury lakes, and survival increased with additions of $\mathrm{Ca}$ or/and $\mathrm{Na}$ to Clearwater lake water.

\section{$\mathrm{Cu}$ and Ni Bioassays in Blue Chalk Lake water (Hypothesis 1)}

The survival of the daphniids decreased monotonically with increasing $\mathrm{Cu}$ and $\mathrm{Ni}$ concentrations in Blue Chalk Lake water. Survival differed between metal treatments and among species $(\mathrm{df}=3, \mathrm{~F}=103.88, \mathrm{P}=0.0001$ among treatments, and $\mathrm{df}=3, \mathrm{~F}=11.86, \mathrm{P}<0.0001$ among species). While none of the four daphniid species survived in Blue Chalk Lake water spiked with $\mathrm{Cu}$ and $\mathrm{Ni}$ at concentrations similar to Middle and Hannah lakes (mortality was $100 \%$ ), they survived in the other treatments, albeit to different degrees (Fig. 2). 


\section{Bioassays with water from the Sudbury lakes (Hypothesis 2)}

The results from the metal-spiked Blue Chalk Lake Bioassay did not provide an accurate guide to the survival of the four daphniids in the bioassays conducted using the actual lake waters from the Sudbury lakes. While the relationship between survival and metal levels in the spiked Blue Chalk Lake water was monotonic and negative, it was not so in the Sudbury lakes. Survival did differ among lakes and among taxa $(\mathrm{df}=3, \mathrm{~F}=35.25, \mathrm{P}<0.0001$ among daphniid species and $\mathrm{df}=5, \mathrm{~F}=81.16, \mathrm{P}<0.0001$ among lakes), but none of the test animals of any of the four daphniid species survived $14 \mathrm{~d}$ in Clearwater Lake water. $D$. ambigua did not survive in water from Middle or Hannah lakes, while the other three species did survive, even though Middle and Hannah lakes have $\mathrm{Cu}$ concentrations twice as high, and Ni concentrations, up to 1.7 times higher than in Clearwater Lake. However, in Middle Lake water, survival of $D$. pulicaria, D. mendotae and D. pulex was similar to survival in the FLAMES medium, Blue Chalk, Joe and Lohi Lake waters. D. ambigua proved to be the most sensitive species with no survival in any of the three lakes with higher metal concentrations (i.e., Clearwater, Middle and Hannah) (Fig 3). Thus, some factors other than total metal concentrations were influencing survival.

\section{Bioassays with Clearwater Lake water (Hypothesis 3)}

The last bioassay was run both to determine that the initial Clearwater Lake result was repeatable, and if so, to determine the cause of the differences in survival between Clearwater and Middle and Hannah lakes, i.e. why there was complete mortality of all daphniid species in the lake with intermediate metal levels within the metal gradient, and survival at the higher total metal concentrations. We

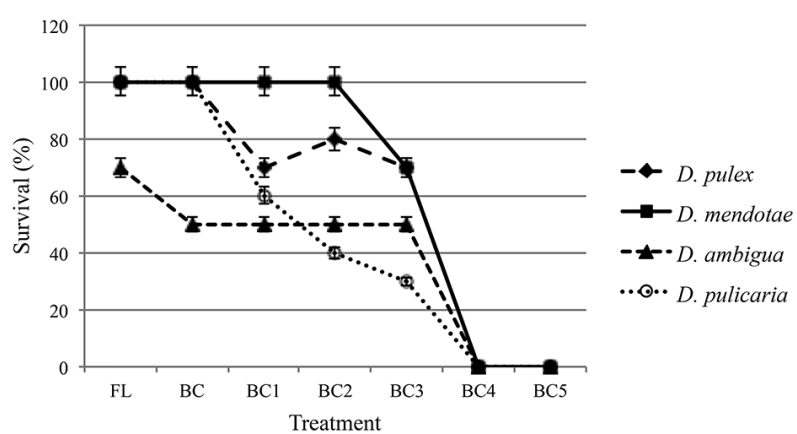

Fig. 2. Survival results (with SE's) for Bioassay 1: 14 day survival of the four Daphnia species in Flames medium (FL), Blue Chalk Lake water (BC) and Blue Chalk Lake water spiked with $\mathrm{Cu}$ and $\mathrm{Ni}$ to the metal concentrations in Joe (BC1), Lohi (BC2), Clearwater (BC3), Middle (BC4) and Hannah (BC5) lakes. hypothesized that increasing the $\mathrm{Ca}$ and/or $\mathrm{Na}$ levels in Clearwater Lake to their concentrations in Middle Lake which had the next higher copper and nickel levels in the gradient, would increase the survival of the daphniids in Clearwater Lake water. Both $\mathrm{Ca}$ and $\mathrm{Na}$ additions to Clearwater Lake enhanced the survival of the daphniids, i.e. hypothesis 3 was supported. All daphniids again died in the unmodified Clearwater Lake water treatment, but $\mathrm{Ca}$ and $\mathrm{Na}$ additions increased their survival. Survival did not differ among treatments when the un-amended Clearwater Lake treatment, where all animals died, was excluded. The four Daphnia species had similar survival rates in Blue Chalk lake water, FLAMES medium, and Clearwater Lake water with added $\mathrm{Ca}$ and/or Na. Survivorship increased from $0 \%$ (all species) in Clearwater Lake water to $80 \%$ in D. ambigua and D. pulicaria, $90 \%$ in D. mendotae and $100 \%$ in D. pulex when Ca in Clearwater Lake water was increased from $4.06 \mathrm{mg} \mathrm{L}^{-1}$ to 9.58 $\mathrm{mg} \mathrm{L}^{-1}$, the level of $\mathrm{Ca}$ present in Middle Lake. Sodium was also protective, but less than $\mathrm{Ca}$ : increasing $\mathrm{Na}$ in Clearwater Lake water from $4.53 \mathrm{mg} \mathrm{L}^{-1}$ to $34.8 \mathrm{mg} \mathrm{L}^{-1}$, the level of $\mathrm{Na}$ present in Middle Lake, increased the survival of daphniids from $0 \%$ to $60 \%$ for $D$. pulicaria, to $70 \%$ for D. ambigua and D. mendotae, and to $90 \%$ for $D$. pulex (Fig. 4). A mixture of $\mathrm{Ca}$ and $\mathrm{Na}$ added to Clearwater Lake water also increased the survival of all four species. Survival increased from $0 \%$ in un-amended water from Clearwater Lake, to $80 \%$ for D. pulex and D. ambigua, $90 \%$ for D. pulicaria, and $100 \%$ for D. mendotae when both the $\mathrm{Ca}$ and $\mathrm{Na}$ levels were increased to the levels of Middle Lake.

The LOI diminished with increased metal concentrations in the Blue Chalk Lake water bioassay $(\mathrm{df}=4$, $\mathrm{F}=12.71, \mathrm{P}<0.0001$ ) among treatments, $\mathrm{df}=3, \mathrm{~F}=16.31$, $\mathrm{P}=2.02$ among species), (Fig. 5) but had no similar response in Bioassay 2 (Fig. 6). In Bioassay 2 the LOI ( $d f=5$,

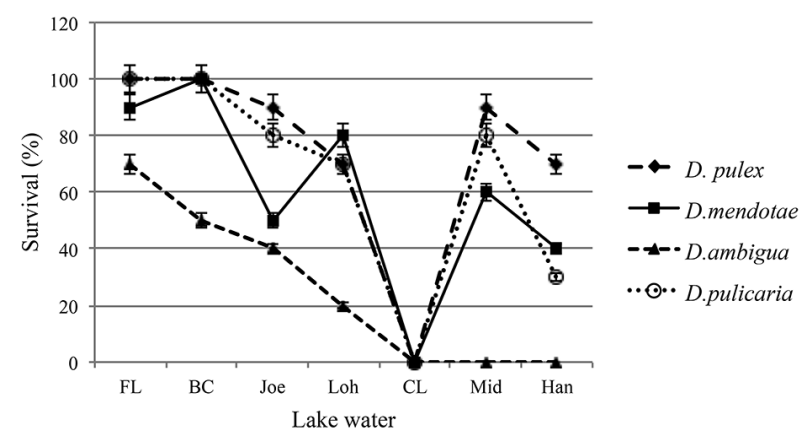

Fig. 3. Survival results (with SE's) for Bioassay 2: 14 day survival of four Daphnia species in Flames medium (FL), and Blue Chalk (BC), Joe (Joe), Lohi (Loh), Clearwater (CL), Middle (Mid) and Hannah (Han) lake waters. 
$\mathrm{F}=14.56, \mathrm{P}<0.0001$ among lakes, $\mathrm{df}=3, \mathrm{~F}=11.12, \mathrm{P}<0.0001$ among species, $\mathrm{df}=3, \mathrm{~F}=7.40, \mathrm{P}=0001$ among treatments) the LOI did not have a monotonic response but increased in Middle and Hannah lakes waters in D. pulex, and decreased with higher metal levels in D. mendotae and $D$. pulicaria. The lowest LOI for D. pulex in Bioassay 2 was observed in Joe and Lohi lakes waters. No significant differences were observed in the LOI of $D$. ambigua.

\section{DISCUSSION}

\section{Survival}

In the Blue Chalk Lake experiment, mortality increased monotonically with increases in metals. There is no reason to believe that reduced survival at higher metal levels was not caused by metal toxicity in these assays. All the animals were reared and tested under the same controlled conditions in culture chambers. Neonates $<24 \mathrm{~h}$ old were used in all cases. The treatment media were prepared $24 \mathrm{~h}$ in advance to allow the medium to become chemically stable, and all animals were fed the same type and amount of food on the same schedule. Hence, the only variable differing among treatments was metal concentrations. We see no reason to reject the hypothesis that metals controlled the survival of the daphniids and were responsible for the decreased survival at the highest levels of $\mathrm{Cu}$ and $\mathrm{Ni}$ in the Blue Chalk assay (Bioassay 1), given the fact that all are above the maximum of $2 \mu \mathrm{g} \mathrm{L}^{-1}$ of $\mathrm{Cu}$ and $25 \mu \mathrm{g} \mathrm{L}^{-1}$ of $\mathrm{Ni}$ recommended for the protection of aquatic life (Ontario Ministry of the Environment and Energy, 1994; Canadian Council of Ministers of the Environment, 2011).

In the Sudbury lakes the survival of the daphniids was non-monotonic and not correlated with increasing metal levels; instead the highest mortality occurred in Clearwater Lake, a lake with intermediate levels of metals among

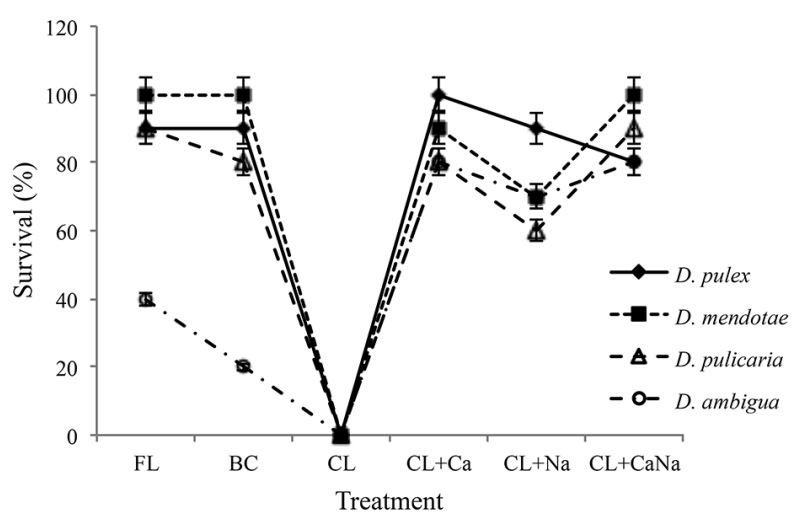

Fig. 4. Survival results (with SE's) for Bioassay 3: 14 day survival of four Daphnia species in Clearwater Lake water (CL) spiked with $\mathrm{Ca}$ and $\mathrm{Na}$ to Middle Lake $\mathrm{Ca}$ and $\mathrm{Na}$ concentrations. our selected suite of lakes. Other factors such as $\mathrm{Ca}$ and $\mathrm{Na}$ must be considered to explain the survival response of the daphniids. We are excluding any influence from dissolved organic carbon, given the fact that Palmer et al. (2013) have indicated that the levels in this parameter are similar in the Sudbury lakes as those present in the reference lake used as control (Blue Chalk Lake).

Additions of $\mathrm{Ca}$ and $\mathrm{Na}$ to Clearwater Lake water increased the survival of the daphniids, indicating that metals are influencing their recovery but that local water

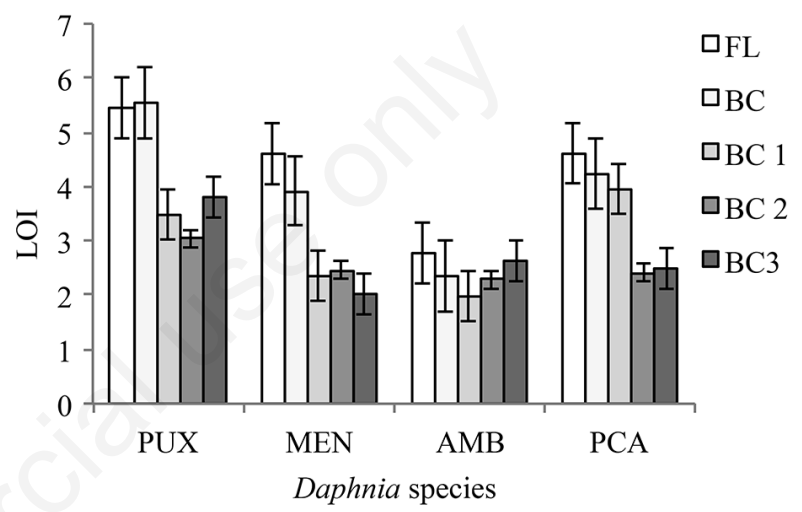

Fig. 5. Average lipid ovary index (with SE's) in Daphnia pulex (PUX), D. mendotae (MEN), D. ambigua (AMB) and D. pulicaria (PCA) in Bioassay 1, using Flames medium (FL), and Blue Chalk Lake water (BC) spiked with $\mathrm{Cu}$ and $\mathrm{Ni}$ to the concentrations found in Joe Lake (BC1), Lohi Lake (BC2) and Clearwater Lake (BC3). There were no survivors in BC4 (Middle Lake) or BC5 (Hannah Lake).

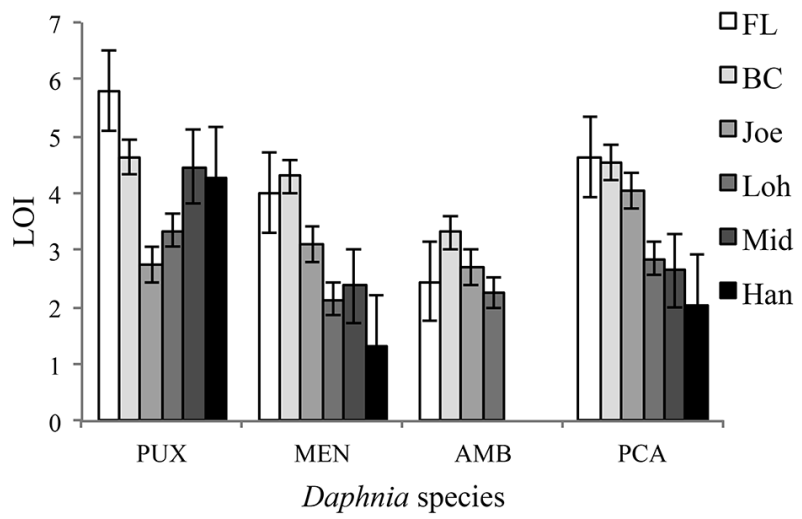

Fig. 6. Average lipid ovary index (with SE's) in Daphnia pulex (PUX), D. mendotae (MEN), D. pulicaria (PCA) and D. ambigua (AMB) in Flames medium (FL) and lake water from: Blue Chalk Lake (BC), Joe Lake (Joe), Lohi Lake (Loh), Middle Lake (Mid) and Hannah Lake (Han). There were no survivors in Clearwater Lake. 
quality is regulating metal toxicity, and thus the pattern of recovery across the landscape. Its lower levels of $\mathrm{Ca}$ and Na likely explain this result, as Bioassay 3 indicated that raising its $\mathrm{Ca}$ and/or $\mathrm{Na}$ levels reduced the water's toxicity. Calcium diminishes the toxicity of metals to daphniids (De Shamphelaere et al., 2007; Kozlova et al., 2009). Middle and Hannah lakes lie on a gabbro bedrock which includes $\mathrm{Ca}$ and/or magnesium rich plagioclase feldspars in its composition in the Sudbury area (Roussell et al., 2003), but the current levels of $\mathrm{Ca}$ in the water in Middle and Hannah lakes are likely derived mainly from the liming manipulations of the lakes and their catchment areas in the past. According to De Schamphelaere and Janssen (2002), the $\mathrm{Cu} 48 \mathrm{~h}$ EC50 for D. magna increases with increases in $\mathrm{Ca}$ and $\mathrm{Na}$ in the water. Deleebeck et al. (2007) also reported a reduction of Ni toxicity with increased water hardness for $D$. longispina and other cladocerans, but sodium has different effects on different species of Cladocera (De Schamphelaere et al., 2007). Such effects were observed in Bioassay 2. Daphniids had higher survival in the lakes with higher Ca concentrations (Middle and Hannah), even though these lakes had 10 times the amount of $\mathrm{Cu}$ as Joe Lake, double the amount of $\mathrm{Cu}$ of Lohi and Clearwater lakes, more than fourteen times the Ni of Joe Lake and more than double the Ni levels of Lohi and Clearwater lakes.

Daphniid survival was the lowest in Clearwater Lake also due to lower $\mathrm{pH}$ levels, probably making the $\mathrm{Cu}$ and Ni bioavailability the highest among the suite of lakes. The speciation of metals including the mix of free ionic, hydroxides or salts, is controlled largely by the $\mathrm{pH}$ of the medium (Vesper et al., 2001; Guthrie et al., 2003), and some metal species are more toxic than others. For freshwater animals, the toxic forms of $\mathrm{Cu}$ are the free ion $\mathrm{Cu}^{2+}$ (Lock et al., 2007) and $\mathrm{CuOH}^{-}$(Borgmann, 2005), and for $\mathrm{Ni}$ the toxic form is the free ion $\mathrm{Ni}^{2+}$ (Lock et al., 2007). Park and Kim's (1985) Cu speciation curves provide information on the form of the metal present in our experiments, while Guthrie et al. (2003) and Vesper et al. (2001) provide information on $\mathrm{Ni}$ speciation. Because the $\mathrm{pH}$ was stable both in the Blue Chalk Lake and in the Clearwater Lake experiments, metal speciation would also have been stable in our treatments, therefore the decreases in survival were caused by the increase in the metal levels, not by a $\mathrm{pH}$-induced change in speciation during the experiment. This was not the case for Bioassay 2, the Sudbury lakes experiment. Here, the $\mathrm{pH}$ of the lakes differed, inducing different speciation for the metals. The $\mathrm{pH}$ ranged from a low of 6.30 in Clearwater Lake to 7.8 in Hannah Lake (Tab. 1). The relative amounts of the toxic species of $\mathrm{Ni}$ and $\mathrm{Cu}$ fall as $\mathrm{pH}$ rises from 6 to 8 (Vesper et al., 2001). Holt and Yan (2003) set pH 6 as the target $\mathrm{pH}$ for recovery from acidification in the absence of metal stress, but $\mathrm{Cu}$ and $\mathrm{Ni}$ are affecting the daphniids at the $\mathrm{pH}$ of
Clearwater Lake compared with the rest of the assay media used in my experiments. Thus, the higher $\mathrm{pH}$ of Middle and Hannah lakes also partially explains the survival results, as less of the $\mathrm{Cu}$ and $\mathrm{Ni}$ would have been in bioavailable forms at the lakes' higher $\mathrm{pH}$ levels.

Despite partial recovery (Keller et al., 2002), the zooplankton communities of Sudbury lakes still do not resemble those in reference lakes (Keller et al., 2007; Palmer et al., 2013). For Clearwater Lake in particular, the greater bioavailability of the metals related to its $\mathrm{pH}$, coupled with lower levels of $\mathrm{Ca}$ and $\mathrm{Na}$ compared with Middle and Hannah lakes explains the reduced survival of daphniids that is likely contributing to their delayed recovery in its zooplankton assemblage.

\section{Lipid ovary index}

The LOI for all species was a useful indicator of the metal stress to which the daphniids were subjected and was related to the increased metals in the Bioassay 1 treatments, but also to the cation levels for $D$. pulex in Bioassay 2 with Sudbury lakes. Tessier and Goulden (1982) developed the LOI as a good indicator because individuals that do not accumulate lipids cannot reproduce, and established that the accumulation of lipids can also be related to food quantity. Food was not a limiting factor in our experiments, since food was always added at concentrations of $1 \mathrm{mg} \mathrm{L}^{-1} \mathrm{~d}^{-1}$ of total particulate carbon, enough so that the growth of the animals would not have been limited by food quantity (Lampert and Schober, 1980). Nonetheless, LOI's decreased with increases in metal levels in Bioassay 1. The presence of abundant food was no guarantee of an increase in the LOI in all treatments; rather, metal exposure reduced ingestion, digestion and/or assimilation so that the rate of lipid incorporation into fat drops was reduced differently in each species of Daphnia. The variations in the LOI values in D. mendotae, D. pulicaria and D. pulex indicate different response to the metal stress and the $\mathrm{Ca}$ and/or $\mathrm{Na}$ availability. The allocation of energy for growth, development and survival may differ among cladoceran species (Tessier and Goulden, 1982). It is possible that energy was being used primarily for physiological needs, leaving less for storage and passage to eggs as yolk. De Coen and Janssen (1998) indicated that available energy is usually diverted from growth and reproduction towards metabolic pathways to cope with metal stress and maintain homeostasis, and this explains our results of reduced LOI towards higher metal concentrations in Bioassay 1, and the reduced LOI in D. mendotae and D. pulicaria in Bioassay 2. The responses of $D$. pulex and $D$. ambigua indicate differences among daphniids in the response to metal stress and metalcation mixes, expressed not only as survival but also as LOI among Daphnia species, interaction that requires further research.

Based on our results for survival and LOI, the state 
of metal toxicity in the Sudbury lakes may be ranked from highest to lowest as: Clearwater $>$ Lohi $>$ Joe $>$ Middle $>$ Hannah. Given that Middle and Hannah lakes had the highest $\mathrm{Cu}$ and Ni levels among these lakes, this is an interesting result especially when $\mathrm{Na}$ was added to Clearwater Lake water. The daphniids seem to have different tolerances both to the metal concentrations used and to the conditions present in the lake waters we employed in this study.

Even though D. ambigua survived poorly in our controls in all three bioassays, we included it in our results due to its response in Bioassay 3, where its survival with added $\mathrm{Ca}$ and $\mathrm{Na}$ was similar to the other three species. We suggest that this response in D. ambigua is pointing at higher demands for the cations in this species, which are critical after the post-molting phase when they are in higher physiological demand, especially $\mathrm{Ca}$ for carapace formation (Hessen et al., 2000).

\section{The role of cations}

Calcium increased the survival of daphniids by up to $90 \%$ in the otherwise lethal Clearwater Lake water. By increasing $\mathrm{Ca}$ to the current levels of Middle Lake, the survival of the four species in Clearwater Lake water increased significantly. The Biotic Ligand Model assumes the competition of $\mathrm{Ca}$ with divalent metals for binding sites on the membranes involved in cation exchange, based on the idea that metal toxicity is related to the amount of free metal ions in the water, plus the metal-ligand complexation on the site of action and, metal competition for the binding site between metals and cations (Di Toro et al., 2001; De Schamphelaere and Janssen, 2002; De Schamphelaere et al., 2005).

Deleebeeck et al. (2007) demonstrated that water hardness between 6.25 and $43.4 \mathrm{mg} \mathrm{CaCO}_{3} \mathrm{~L}^{-1}$ had a protective effect for Ni to Cladocera. De Schamphelaere and Janssen (2002), and Kozlova et al. (2009) utilizing the Biotic Ligand Model for D. magna and D. pulex, respectively, proved that increased $\mathrm{Ca}$ in the water increased the $\mathrm{Cu} 48$ h EC50. Divalent metals such as $\mathrm{Cu}$ compete with $\mathrm{Ca}$ and $\mathrm{Mg}$ and with hydrogen ions for membrane binding sites on fish gills (Santore et al., 2001; Pyle et al., 2002; Niyogi and Wood, 2004). By competing with cations, metals disrupt the $\mathrm{Ca}$ balance and the Na-potassium pump (Fisher and Hook, 2002; Slaveyková and Wilkinson, 2005) altering the cell's signaling processes on all cellular membranes (Pritchard, 1993). Free divalent $\mathrm{Cu}$ competes with divalent $\mathrm{Ca}$ for binding sites on cellular membranes (Playle and Wood, 1989; Playle et al., 1992; De Schamphelaere and Janssen, 2002). In the case of the Clearwater experiment (Bioassay 3), the increased amount of $\mathrm{Ca}$ counteracted the $\mathrm{Cu}$ and $\mathrm{Ni}$ effects. At an increased concentration of $\mathrm{Ca}$ with the same concentration of the divalent metals, the competition for binding sites would have been increased and less of the $\mathrm{Cu}$ and $\mathrm{Ni}$ would have been bound to the membranes and taken up by the animals. Given that the $\mathrm{pH}$ remained constant, and there was no obvious change in other binding ligands such as dissolved organics, the survival of the daphniids in the Clearwater Lake experiments with added $\mathrm{Ca}$ and $\mathrm{Na}$ is explained by this competition effect. For the $\mathrm{Cu}$ and $\mathrm{Ni}$ levels in Clearwater Lake (8.9 $\mu \mathrm{g} \mathrm{L} \mathrm{L}^{-1}$ and $79.9 \mu \mathrm{g} \mathrm{L}^{-1}$ respectively), at $\mathrm{pH}$ of 6.3 , it appears that the Ca levels in the lake $\left(4.06 \mathrm{mg} \mathrm{L}^{-1}\right)$ are not offering enough protection from the metals to permit survival let alone maturation and reproduction in these animals. According to Deleebeeck et al., (2007) the hardness of the water as $\mathrm{CaCO}_{3}$ has a protective effect from $\mathrm{Ni}$ to Cladocera. When the Ca levels in Clearwater Lake water were increased to similar in value to those present in Middle Lake levels $\left(9.58 \mathrm{mg} \mathrm{L}^{-1}\right)$, the competitive benefits were evident, as their survival approached levels of both the Flames and Blue Chalk Lake controls.

Sodium increased the survival of daphniids $>60 \%$ in the otherwise lethal Clearwater Lake water. Sodium chloride is harmful to freshwater biota at concentrations higher than those found in Sudbury lakes. Martínez-Jerónimo and Martínez-Jerónimo (2007) determined a reduction in fecundity in cladocerans at $0.06 \mathrm{~g} \mathrm{~L}^{-1}$ levels not too different from Hannah Lake, the highest in the suite of lakes. De Schamphelaere and Janssen (2002) determined an increase in the $48 \mathrm{~h} \mathrm{Cu}$ EC50 for Daphnia magna with an increase in $\mathrm{Na}$ in the water. Even though the $\mathrm{Ni}^{2+}$ form is bioavailable through mechanisms similar to those for $\mathrm{Cu}$ and $\mathrm{Ca}$ on the cell membrane, there are no clear indications for $\mathrm{Na}$ affecting mechanisms of $\mathrm{Ni}$ uptake or toxicity, $\mathrm{Na}$ being a univalent element. Nonetheless, when we increased the Na level of Clearwater Lake water from its ambient level of $4.53 \mathrm{mg} \mathrm{L}^{-1}$ to the 34.08 $\mathrm{mg} \mathrm{L}^{-1}$ as in Middle Lake, daphniid survival at $14 \mathrm{~d}$ increased from $0 \%$ to $>60 \%$ for all species. This indicates that $\mathrm{Na}$ at these levels offered protection to the daphniids from the effects of $\mathrm{Cu}$ and $\mathrm{Ni}$.

The effect of $\mathrm{Na}$ can be explained based on the activity of the sodium-potassium ATPase. In D. magna this enzyme is altered in the presence of $\mathrm{Cu}$ (Bianchini and Wood, 2008) thus causing an indirect effect on the availability of potassium. The effect of the metal on this enzyme alters the osmoregulatory process through the sodium-potassium pump at the cell membrane, causing an increasing loss of $\mathrm{Na}$ with a related increasing potassium concentration in the body. Since high potassium causes an inhibition in the heart beat rate of D. magna at concentrations of $0.04 \mathrm{M}$ (Baylor, 1942) the higher levels of potassium derived from the metal-induced impairment of the sodium-potassium pump may be also affecting the survival of the daphniids. The higher Na concentrations also appear to be helpful in order to cope with the osmoregulatory stress promoted by $\mathrm{Cu}$. 


\section{Implications for recovery}

Assuming we have not worked with clones that have unusual toxicological responses to $\mathrm{Cu}$ and $\mathrm{Ni}$ and perhaps other metals found in Sudbury lakes, our survival results indicate that the recovery of the four common species of Ontario daphniids should not be limited by metal toxicity per se in Sudbury lakes, and that metal toxicity should not limit the current ability of $D$. pulex, D. mendotae and $D$. pulicaria to establish populations in Middle and Hannah lakes. However, LOI results in this study indicate that metal stress affected the energy balance of our animals. The continuing absence of robust populations of three of the species in the lakes also indicates that conditions other than those we analyzed may be preventing their re-establishment. These factors could include absence of adequate food, competition, predation or climate change among others (Keller, 2007; Luek et al., 2010; Valois et al., 2010).

All the daphniid species we employed are present in the region, and have been observed in the lakes in the past. Yan et al. (1996b) reported D. pulex and D. mendotae in the study lakes, and the Ontario Ministry of the Environment and Climate Change zooplankton data sets from 1970 - 2014 also indicate the occasional presence of $D$. ambigua and D. pulicaria, therefore, colonizers are available. Cladocerans may have been introduced by waterfowl from great distances (Frisch and Green, 2007), or by people from many other undamaged lakes with rich zooplankton assemblages (Yan et al., 2008) in the region. Non-daphniid cladocerans and many copepod species currently inhabit the lakes (Yan et al., 1996a; Keller and Yan, 1998, Keller et al., 2002).

Food availability is likely not limiting daphniid recovery. The phytoplankton composition in the lakes in Sudbury, and specifically in Clearwater Lake, the critical lake in our study, has recovered to the point where it cannot be distinguished, at least on the basis of genus composition, from reference lakes (Keller et al., 2007; Winter et al., 2008). Thus, lack of food availability is likely not the reason for their absence in the Sudbury study lakes. The phytoplankton community supports varied zooplankton communities in Sudbury lakes with herbivores represented by copepods and cladocerans including $D$. mendotae in Middle and Hannah lakes. D. pulicaria, D. catawba, D. longiremis, D. pulex, D. retrocurva, Eubosmina tubicen, Holopedium glacialis and, calanoid and cyclopoid copepods have been recorded in the past in Middle Lake (Keller et al., 2007). Lohi and Clearwater lakes are dominated by Holopedium sp. and have no daphniids, while $D$. mendotae is the occurring species in Middle and Hannah lakes with no Holopedium sp. present. These contrasts indicate conditions are currently still challenging for daphniids in Lohi and Clearwater lakes. While food availability may be sufficient, food quality may not be. Phytoplankton and bacteria, the main food of daphni- ids, are also facing environmental challenges in Sudbury lakes; different groups of algae have different biochemical composition (Guschina and Hardwood, 2009) and shifts in their populations and/or their own response to the environmental stressors in Sudbury lakes may have effects on their biochemistry and nutritional value as food for the herbivores.

The possibility that the levels of $\mathrm{Ca}$ and $\mathrm{Na}$ are affecting the re-establishment of Daphnia species in the metal stressed lakes was analyzed by comparing the current concentrations of those cations with published effects on daphniid survival and reproduction. The differences in $\mathrm{Ca}$ concentrations in the set of lakes compared with the Flames medium and with Blue Chalk Lake are: zero for Joe Lake, 1.7 times higher for Lohi and Clearwater lakes, and 3.7 times higher and 4.3 times higher, respectively for Middle and Hannah lakes. Sodium is 1.6 times higher in Joe Lake, 6.27 times higher in Lohi Lake, 7.15 times higher in Clearwater Lake, 48.1 times higher in Middle Lake and 85.9 times higher in Hannah Lake. All the lakes have $\mathrm{Ca}$ levels above the limiting level of $1.5 \mathrm{mg} \mathrm{L}^{-1}$ needed to sustain D. pulex in the field (Ashforth and Yan, 2008; Jeziorski et al., 2008). As for Na concentrations, Martínez-Jerónimo and Martínez-Jerónimo (2007) observed fecundity effects in D. magna starting at $0.06 \mathrm{~g} \mathrm{~L}^{-}$ ${ }^{1}$, and the study lakes are all below that toxic threshold. Thus, the concentration of both cations may not be harmful to the daphniids in the lakes. Ashforth and Yan (2008) used D. pulex, and Martínez-Jerónimo and MartínezJerónimo (2007) tested D. magna, both pond species and therefore potentially more tolerant to environmental changes than the lake species we used. The limiting needs of $\mathrm{Ca}$ for species other than D. pulex and the tolerance levels to Na in very soft waters for local Daphnia species in the Ontario Canadian Shield lakes are not known.

$\mathrm{Ca}$ levels are decreasing in most Canadian Shield lakes in Ontario, mainly in response to declining acid deposition rates (Keller et al., 2001; Jeziorski et al., 2008), while $\mathrm{Na}$ levels are often increasing, mainly in lakes affected by winter road salting operations. With the decrease in $\mathrm{Ca}$, the $\mathrm{Cu}$ and $\mathrm{Ni}$ concentrations may become toxic again imposing physiological stress on colonizing daphniids. Even when the gradient of metals in the lakes was: Hannah Lake $>$ Middle Lake $>$ Clearwater Lake $>$ Lohi lake $>$ Joe Lake, the presence of $\mathrm{Ca}$ and $\mathrm{Na}$ in those lakes led to a different sequence of observed toxicity: Clearwater Lake $>$ Hannah Lake $>$ Middle Lake $>$ Lohi Lake $>$ Joe Lake.

Determining the regulators and degree of recovery of ecosystems from multiple historical stressors is complicated (Oneill, 1999). Future progress in the recovery of Daphnia species in Sudbury lakes will depend on the future trends of $\mathrm{pH}$, cations and metals, and potentially on additional stressors such as climate change (Keller, 2007). 
The effects of predation, competition and the introduction of non-native species may also play a role (Keller, 2009; Luek et al., 2010), as well as the possibility of colonization by genetically adapted regional clones in the Sudbury area, as potentially better fitted for surviving and establishing successful colonies in the still metal contaminated lakes (Shaw et al., 2007).

Designating an ecosystem as recovered can be approached from the perspectives of function, species richness or composition (Temperton et al., 2004). From a functional perspective, the presence of a pelagic herbivore community in the study lakes represented by copepods and cladocerans other than Daphnia species could be interpreted as recovery. However, Gray and Arnott (2009) suggest that species richness is not the best indication of recovery; therefore, metrics other than that should be included in the evaluation of recovery trends in the Sudbury lakes. Damaged ecosystems may not always be able to return to a pre-disturbance state, even when the chemical and other biological stressors are removed (Cairns, 1990; Keller, 2009): however, when the species failing to re-establish are one of the most sensitive groups of invertebrates to water quality contaminants such as daphniids, one can conclude that the habitat is still stressful assuming that recovery has not been limited by colonist supply.

\section{CONCLUSIONS}

Quantifying the patterns of daphniid survival along a gradient of metal contamination in the laboratory helped determine the potential for their recovery in the zooplankton communities of Sudbury lakes. Our results indicate that there are thresholds for the survival of daphniids in these lakes related to the balance between concentrations of metals and cations. Obtaining more precise estimates of these thresholds will enhance our understanding of the factors that affect not only the survival but the establishment of populations of daphniids under metal stress at dif- ferent metal and cation concentrations in Sudbury lakes. We determined that an empirical threshold lies in the $\mathrm{Cu}$ $\mathrm{Ni}$ and $\mathrm{Ca}-\mathrm{Na}$ levels between Clearwater and Middle lakes. The use of native species from the region and a regional reference lake helped us to further understand this potential, and provided ecotoxicological information for these species never before tested under the soft water conditions employed in this study. Our results also suggest that native daphniid species differ in their ability to withstand $\mathrm{Cu}$ and $\mathrm{Ni}$ stress, in the presence of $\mathrm{Ca}$ and $\mathrm{Na}$ in the water (Tab. 4). How the thresholds for different combinations of metals and cations will vary among $\mathrm{Cu}, \mathrm{Ni}$, $\mathrm{Na}$ and $\mathrm{Ca}$ levels as well as among Daphnia species requires further research.

These results are a first step in quantifying the interactions of $\mathrm{Ca}$ and $\mathrm{Na}$ with $\mathrm{Cu}$ and $\mathrm{Ni}$ on native daphniid species from the Canadian Shield. As such, they may be useful in interpreting data from zooplankton monitoring programs in areas with acidification and/or metal impacts, as well as to enrich the methodologies for setting water quality regulations in soft water. They also provide a useful addition to the understanding of the mosaic of patterns of biological recovery in the Sudbury lakes of the Canadian Shield.

\section{ACKNOWLEDGEMENTS}

This work was supported by the National Science and Engineering Research Council of Canada, the Cooperative Freshwater Ecology Unit -Laurentian University, the Vale and Glencore mining companies, the Field Laboratory for the Assessment of Multiple Ecological StressorsYork University, the Ontario Ministry of the Environment and Climate Change-Dorset Environmental Science Centre and Sudbury, Consejo Nacional de Ciencia y Tecnología de México, and the Canadian Phycological Culture Collection-University of Waterloo. Lynne Witty, Don Evans, Peter Sutey, Ron Ingram, Dallas Linley, Crys-

Tab. 4. Information used to assess the potential for recovery of the four Daphnia species in the studied Sudbury lakes based on $>80 \%$ survival in $14 \mathrm{~d}$ in Bioassay 1 (Blue Chalk Lake water spiked with $\mathrm{Cu}$ and $\mathrm{Ni}$ ), in Bioassay 2 (the actual Sudbury lakes waters), and comparing it to the presence of daphniids in the lakes.

\begin{tabular}{lccc} 
Treatment or lake & Bioassay 1 & Bioassay 2 & Daphinia species present in the \\
BC $1 /$ Joe Lake & D. mendotae & D. pulex & Sudbury lakes* \\
BC $2 /$ Lohi Lake & D. pulex & D. pulicaria & D. pulicaria \\
\hline BC $3 /$ Clearwater Lake & D. mendotae & D. mendotae & None \\
BC $4 /$ Middle Lake & None & None & None \\
\hline BC $5 /$ Hannah Lake & None & D. pulex & D. mendotae
\end{tabular}

*Data courtesy of the Ontario Ministry of the Environment and Climate Change 1970-2014. 
tal Hyatt, Andreas Luek and George Morgan contributed to various aspects of this work. We thank the two anonymous reviewers who kindly provided very useful comments to an earlier version of this paper.

\section{REFERENCES}

Ashforth D, Yan ND, 2008. The interactive effects of calcium concentration and temperature on the survival and reproduction of Daphnia pulex at high and low food concentrations. Limnol. Oceanogr. 53:420-432.

Baylor ER, 1942. Cardiac pharmacology of the cladoceran Daphnia. Biol. Bull. 83:165-172.

Bianchini A, Wood CM, 2008. Sodium uptake in different life stages of crustaceans: the water flea Daphnia magna Strauss. J. Exp. Biol. 211:539-547.

Bielmeyer GK, Brix KV, Capo TR, Grosell M, 2005. The effects of metals on embryo-larval and adult life stages of the sea urchin, Diadema antillarum. Aquat.Toxicol. 74:254-263.

Boerner DE, Milkereit B, Davidson A, 2000. Geoscience impact: a synthesis of studies of the Sudbury structure. Can. J. Earth Sci. 37:477-501.

Borgmann U, Nowierski M, Dixon DG, 2005. Effect of major ions on the toxicity of copper to Hyallela azteca and implications for the biotic ligand model. Aquat. Toxicol. 73:268-287.

Cairns J Jr, 1990. Lack of theoretical basis for predicting rate and pathways of recovery. Environ. Manage. 14:517-526.

Canadian Council of Ministers of the Environment, 2011. Canadian water quality guidelines for the protection of aquatic life: chloride. Canadian environmental quality guidelines.

Canli M, 2006. Effects of copper pre-exposure routes on the energy reserves and subsequent copper toxicity in Daphnia magna. Environ.Toxicol. 21:521-527.

Celis-Salgado M, Cairns A, Kim N, Yan ND, 2008. The FLAMES medium: a new, soft water culture and bioassay medium for Cladocera. Verh. Int.-Verein. Limnol. 30:265-271.

Cowgill UM, Milazzo DP, 1991.The sensitivity of two cladocerans to water quality variables: salinity $<467 \mathrm{mg} \mathrm{NaCl} / \mathrm{L}$ and hardness $<200 \mathrm{mg} \mathrm{CaCO}_{3} / \mathrm{L}$. Arch. Environ. Con. Tox. 21:218-223.

De Coen WM, Janssen CR, 1998. The use of biomarkers in Daphnia magna toxicity testing. Hydrobiologia 367:199-209.

Deleebeeck NM, Muyssen BT, De Laender F, Janssen CR, De Schamphelaere KA, 2007. Comparison of nickel toxicity to cladocerans in soft versus hard surface waters. Aquat.Toxicol. 84:223-235.

De Schamphelaere KAC, Forrez I, Dierckens K, Sorgeloos P, Janssen CR, 2007. Chronic toxicity of dietary copper to Daphnia magna. Aquat. Toxicol. 81:409-418.

De Schamphelaere KAC, Janssen CR, 2002. A biotic ligand model predicting acute copper toxicity for Daphnia magna: The effects of calcium, magnesium, sodium, potassium, and pH. Environ. Sci. Technol. 36:48-54.

De Schamphelaere KAC, Lofts S, Janssen CR, 2005. Bioavailability models for predicting acute and chronic toxicity of zinc to algae, daphnids, and fish in natural surface waters. Environ. Toxicol. Chem. 24:1190-1197.

Di Toro DM, Allen HE, Bergman HL, Meyer JS, Paquin PR, Santore RS, 2001. Biotic ligand model of the acute toxicity of metals. 1. Technical basis. Environ. Toxicol. Chem. 20:2383-2396.

FAO, 1996. Manual on the production and use of live food for aquaculture. Laboratory of aquaculture and Artemia reference center, Ghent: 295 pp.

Faulkenham SE, Hall RI, Dillon PJ, Karts-Riddoch T, 2003. Effects of drought-induced acidification on diatom communities in acid-sensitive Ontario lakes. Limnol. Oceanogr. 48:1662-1673.

Fisher NS, Hook SE, 2002. Toxicology tests with aquatic animals need to consider trophic transfer of metals. Toxicology 181-182:531-536.

Frisch D, Green AJ, 2007. Copepods come in first: rapid colonization of new temporary ponds. Arch. Hydrobiol. 168:289-297.

Gliwicz ZM, 1990. Food thresholds and body size in cladocerans. Nature 343:638-640.

Graham MD, Keller B, Heneberry J, Nicholls KH, Findlay D, 2007. Comparative responses of phytoplankton during chemical recovery in atmospherically and experimentally acidified lakes. J. Phycol. 43:908-923.

Gray DK, Arnott SE, 2009. Recovery of acid damaged zooplankton communities: measurement, extent and limiting factors. Environ. Rev. 17:81-99.

Griffith B, Johnston CA, Scott JM, Carpenter JW, Reed C, 1989. Translocation as species conservation tool: status and strategy. Science 245:477-480.

Gunn JM, Keller W, 1990. Biological recovery of an acid lake after reductions in industrial emissions of sulphur. Nature 345:431-433.

Gunn, JM, Sandoy S, 2003. Introduction to the Ambio special issue on biological recovery from acidification: northern lakes recovery study. Ambio 32:162-169.

Guschina IA, Hardwood JL, 2009. Algal lipids and effect of the environment on their biochemistry, p. 1-24. In: M.T. Arts, M.J. Brett and M.J. Kainz (eds.), Lipids in aquatic ecosystems. Springer.

Guthrie JW, Mandal R, Salam MSA, Hassan NM, Murimboh J, Chakrabarti CL, Back MH, Grégoire DC, 2003. Kinetic studies of nickel speciation in model solutions of a wellcharacterized humic acid using the competing ligand exchange method. Anal. Chim. Acta 480:157-169.

Hairston NG, Kearns CM, Demma LP, Effler SW, 2005. Speciesspecific Daphnia phenotypes: a history of industrial pollution and pelagic ecosystem response. Ecology 86:1669-1678.

Havens KE, Yan ND, Keller W, 1993. Lake acidification - Effects on crustacean zooplankton populations. Environ. Sci. Technol. 27:1621-1624.

Hebert PDN, 1995. The Daphnia of North America: an illustrated fauna. CD_ROM, University of Guelph. Guelph, Ontario.

Hessen DO, Alstad NEW, Skardal L, 2000. Calcium limitation in Daphnia magna. J. Plankton Res. 22553-568.

Holt C, Yan ND, 2003. Recovery of crustacean zooplankton communities from acidification in Killarney Park, Ontario, 1971-2000: pH 6 as a recovery goal. Ambio 32:203-207.

Jeffries DS, Clair TA, Couture S, Dillon PJ, Dupont J, Keller W, McNicol DK, Turner MA, Vet R, Weeber R, 2003. Assessing the recovery of lakes in southeastern Canada from the effects of acidic deposition. Ambio 32:176-182.

Jeziorski A, Yan ND, Paterson A, DeSellas A, Turner MA, Jeffries DS, Keller B, Weeber RC, McNicol DK, Palmer ME, 
McIver K, Arseneau K, Ginn BK, Cumming BF, Smol JP, 2008. The widespread threat of calcium decline in fresh waters. Science 322:1374-1377.

Keller W, 2007. Implications of climate warming for Boreal Shield lakes: a review and synthesis. Environ. Rev. 15:99-112.

Keller W, 2009. Limnology in northeastern Ontario: from acidification to multiple stressors Can. J. Fish. Aquat. Sci. 66:1189-1198.

Keller W, Dixit SS, Heneberry J, 2001. Calcium declines in northeastern Ontario lakes. Can. J. Fish. Aquat. Sci. 58:2011-2020.

Keller W, Heneberry J, Dixit SS, 2003. Decreased acidic deposition and the chemical recovery of Killarney, Ontario, Canada. Ambio 32:183-189.

Keller W, Heneberry J, Gunn JM, 1999. Effects of emission reductions from Sudbury smelters on the recovery of acid-and metal-damaged lakes. J. Aquat. Ecosyst. Stress Recovery 6:189-198.

Keller W, Pitblado JR, 1984. Crustacean plankton in northeastern Ontario lakes subjected to acidic deposition. Water Air Soil Poll. 23:271-291.

Keller W, Pitblado JR, 1989. The distribution of crustacean zooplankton in northern Ontario, Canada. J. Biogeography. 16:249-259.

Keller W, Yan ND, 1991. Recovery of crustacean zooplankton species richness in Sudbury area lakes following water quality improvements. Can. J. Fish. Aquat. Sci. 48:1635-1644.

Keller W, Yan ND, 1998. Biological recovery from lake acidification: zooplankton communities as a model of patterns and processes. Restor. Ecol. 6:364-375.

Keller W, Yan ND, Gunn JM, Heneberry J, 2007. Recovery of acidified lakes: lessons from Sudbury, Ontario, Canada. Water Air Soil Poll. Focus 7:317-322.

Keller W, Yan ND, Holtze KE, Pitblado JR, 1990. Inferred effects of lake acidification on Daphnia galeata mendotae. Environ. Sci. Technol. 24:1259-1261.

Keller W, Yan ND, Somers K, Heneberry JH, 2002. Crustacean zooplankton communities in lakes recovering from acidification. Can. J. Fish. Aquat. Sci. 59:726-735.

Khan F, Keller WB, Yan ND, Welsh PG, Wood CM, McGeer JC, 2012. Application of biotic ligand and toxic unit modeling approaches to predict improvements in zooplankton species richness in smelter-damaged lakes near Sudbury, Ontario. Environ. Sci. Technol. 46:1641-1649.

Koivisto S, Ketola M, 1995. Effects of copper on life-history traits of Daphnia pulex and Bosmina longirostris. Aquat. Toxicol. 32:255-269.

Kozlova T, Wood CM, McGeer JC, 2009. The effect of water chemistry on the acute toxicity of nickel to the cladoceran Daphnia pulex and the development of a biotic ligand model. Aquat. Toxicol. 91:221-228.

Lampert W, Schober U, 1980. The importance of "threshold" food concentrations, p. 264-267. In: W.C. Kerfoot (ed.), Evolution and Ecology of Zooplankton Communities. University Press of New England.

Lesher CM, Thurston PC, 2002. A special issue devoted to the mineral deposits of the Sudbury Basin. Econ. Geol. 97:1373-1375.

Lippert KA, Gunn JM, Morgan GE, 2007. Effect of colonizing predators on yellow perch (Perca flavescens) populations in lakes recovering from acidification and metal stress. Can. J. Fish. Aquat. Sci. 64:1413-1428.
Lock K, Van Eeckhout H, De Schamphelaere KAC, Criel P, Janssen CR, 2007 Development of a biotic ligand model (BLM) predicting nickel toxicity to barley (Hordeum vulgare). Chemosphere: 66:1346-1352.

Luek A, Morgan GE, Wissel B, Gunn JM, Ramcharan CW, 2010. Rapid and unexpected effects of piscivore introduction on trophic position and diet of perch (Perca flavescens) in lakes recovering from acidification and metal contamination. Freshwater Biol. 55:1616-1627.

Martínez-Jerónimo F, Martínez-Jerónimo L, 2007. Chronic effect of $\mathrm{NaCl}$ salinity on a freshwater strain of Daphnia magna Straus (Crustacea: Cladocera): a demographic study. Ecotox. Environ. Safe. 67:411-416.

Mason B, 1966. Geochemistry and meteorites. Geochim. Cosmochim. Ac. 80:365-374.

Mertz W, 1981. The essential trace elements. Science 213: 1332-1338.

Nicholls, KH, Nakamoto L, Keller W, 1992. Phytoplankton of Sudbury area lakes (Ontario) and relationships with acidification status. Can. J. Fish. Aquat. Sci. 49(Suppl. 1):40-51.

Niyogi S, Wood CM, 2004. Biotic ligand model, a flexible tool for developing site-specific water quality guidelines for metals. Environ. Sci.Technol. 38:6177-6192.

O’Neill RV, 1999. Recovery in complex ecosystems. J. Aquat. Ecosyst. Stress Recovery 6:181-187.

Ontario Ministry of the Environment and Energy, 1994. Policies, guidelines, provincial water quality objectives of the ministry of environment and energy. Water Management, appendix A.

Palmer ME, Keller W, Yan ND, 2013. Gauging recovery of zooplankton from historical acid and metal contamination: the influence of temporal changes in restoration targets. J. Appl. Ecol. 50:107-118.

Park CK, Kim US, 1985. Prediction of species of chemical species of copper and cadmium in natural waters. J. Korean Chem. Soc. 29:637-645.

Playle RC, Wood CM, 1989. Water chemistry changes in the gill micro-environment of rainbow trout: experimental observations and theory. J. Comp. Physiol. B 159:527-537.

Playle RC, Gensemer RW, Dixon DG, 1992. Copper accumulation of gills of fathead minnows - influence of water hardness, complexation and $\mathrm{pH}$ of the gill microenvironment. Environ. Toxicol. Chem. 11:381-391.

Pritchard JB, 1993. Aquatic toxicology: past, present and prospects. Environ. Health Persp. 100:249-257.

Pyle GG, Swanson SM, Lehmkuhl DM, 2002. The influence of hardness, $\mathrm{pH}$, suspended solids on the nickel toxicity to larval fathead minnows (Pimephales promelas). Water Air Soil Poll. 133:215-226.

Rousell DH, Fedorowich JS, Dressler BO, 2003. Sudbury Breccia (Canada): a product of the 1850 Ma Sudbury Event and host to footwall $\mathrm{Cu}-\mathrm{Ni}-\mathrm{PGE}$ deposits. Earth-Sci. Rev. 60:147-174.

Santore RC, Di Toro DM, Paquin PR, Allen HE, Meyer JS, 2001. Biotic ligand model of the acute toxicity of metals. 2 . Application to acute copper toxicity in freshwater fish and Daphnia. Environ. Toxicol. Chem. 20:2397-2402.

Schartau AK, Halvorsen G, Walseng B, 2007. Northern lakes recovery study (NLRS) - microcrustaceans. Reference conditions, acidification and biological recovery. Norwegian Institute for Nature Research report 235. 66 pp. 
Shaw JR, Colbourne JK, Davey JC, Glaholt SP, Hampron TH, Chen CY, Folt CL, Hamilton JW, 2007. Gene response profiles for Daphnia pulex exposed to the environmental stressor cadmium reveals novel crustacean metallothioneins. BMC Genomics 8:477.

Slaveyková VI, Wilkinson KJ, 2005. Predicting the bioavailability of metals and metal complexes: critical review of the biotic ligand model. Envir. Chem. 2:9-24.

Temperton VM, Hobbs RJ, Nuttle T, Halle S, 2004. Assembly rules and restoration ecology. Bridging the gap between theory and practice. Island Press: $439 \mathrm{pp}$.

Tessier AJ, Goulden CE, 1982. Estimating food limitations in cladoceran populations. Limnol. Oceanogr. 27:707-717.

Valois A, Keller W, Ramcharan C, 2010. Abiotic and biotic processes in lakes recovering from acidification: the relative roles of metal toxicity and fish predation as barriers to zooplankton re-establishment. Freshwater Biol. 55:2585-2597.

Valois AE, Keller W, Ramcharan CW, 2011. Recovery in a multiple stressor environment: using the reference condition approach to examine zooplankton community change along opposing gradients. J. Plank. Res. 33:1417-1429.

Vesper DJ, Loop CM, White W, 2001. Contaminant transport in karst aquifers. Theor. Appl. Karstol. 13-14:101-111.

Webster N, Keller W, Ramcharan C, 2013. Restoration of zooplankton communities in industrially damaged lakes: influ- ences of residual metal contamination and the recovery of fish communities. Restor. Ecol. 21: 785-792.

Winter JG, Keller W, Paterson AM, Yan ND. 2008. Three decades of recovery of the phytoplankton community in Clearwater Lake (Sudbury, Canada) from acid and metal contamination. Verh. Int.-Verein. Limnol. 30:247-252.

Yan ND, Girard R, Heneberry JH, Keller W, Gunn JM, Dillon PJ, 2004. Recovery of copepod, but not cladoceran, zooplankton from severe and chronic effects of multiple stressors. Ecol. Lett. 7:452-460.

Yan ND, Keller W, Somers KM, Pawson TW, Girard RE, 1996a. Recovery of crustacean zooplankton communities from acid and metal contamination: comparing manipulated and reference lakes. Can. J. Fish. Aquat. Sci. 53:1301-1327.

Yan ND, Somers KM, Girard RE, Paterson A, Keller B, Ramcharan C, Rusak J, Ingram R, Morgan G, Gunn JM, 2008. Long-term changes in crustacean zooplankton communities of Dorset, Ontario lakes: the probable interactive effects of changes in $\mathrm{pH}, \mathrm{TP}$, dissolved organic carbon, and predators. Can. J. Fish. Aquat. Sci. 65:862-877.

Yan ND, Welsh PG, Lin H, Taylor DJ, Filion J-M, 1996b. Demographic and genetic evidence of the long-term recovery of (Daphnia galeata mendotae) (Crustacea: Daphniidae) in Sudbury lakes following additions of base: the role of metal toxicity. Can. J. Fish. Aquat. Sci. 53:1328-1344. 